\title{
The shifting use of animal carcasses in medieval and post-medieval London
}

\section{Lisa Yeomans}

\section{Introduction}

The supply and use of post-mortem products obtained from animal carcasses in the high and late medieval are compared to that in the post-medieval periods. The purpose of extending the discussion beyond the conference theme of the Middle Ages is to demonstrate a change in the supply of animal carcasses to urban craftsmen. Raw material distribution networks, location of workshops, scale of production and manufacturing methods can all influence how animal carcasses were used. Such factors were affected by practical issues such as supply but they were also influenced the organisation of work in the urban environment and the wider socio-economic climate. A considerable amount of historical research has focused on the economic developments between the medieval period and the modern day. It is therefore interesting to examine how the industries processing the carcasses of animals did or did not adapt as the regulated crafts were eventually replaced by an industrial and capitalist economy. These industries are of particular significance since the production of goods from animal carcasses remained essentially the same technologically throughout this period suggesting that external pressures were largely responsible for any changes in production strategies.

The results presented in this paper demonstrate how important the supply of raw materials was to the urban craftsmen in the medieval and post-medieval periods. Agricultural developments and enclosure of common land in the countryside had an impact on the animals that were available to the urban population. Supply between craftsmen was also a major influence as was the changing economic structure of late medieval and early post-medieval London.

\section{Craft and industry}

Comparing the cultural norms of medieval guild controlled production to the industrial factory based methods of manufacture that fully emerged during the 19th century gives an impression of the extent of organisational change in processing animal carcasses. Much of this development occurred between the late medieval period and 18th century, a time which marked a divide between two very different manufacturing 
strategies (c.f. Marshall 1929). In many industries the change was not just related to the organisation of the work, changing manufacturing processes allowing production on a larger and larger scale. Such technical developments must have fuelled the changes in the organisation of production but alone they could not have been responsible. The carcass processing industries in which the basic methods were not improved upon until the 19th century demonstrates this.

Medieval guilds were supposedly governed by strict regulations, recorded in numerous ordinances, aimed at protecting the interests of members who practiced similar trades. It is easy to assume that this role was the main function of the organisations because it formed the documented objective. The actual situation was probably somewhat different and a lack of strict coherence to the guild ordinances is often demonstrated by wills and court rolls showing the wide-range of employment that men, as well as women, undertook. The Statute of 1363, which stated that every merchant was to keep to one trade and every artificer but one mystery, was regularly not observed. Numerous documentary sources illustrate how individuals varied their employment through life or on a seasonal basis. Recently, a number of historians have argued that the power of the guilds in organising work in the towns was less effective than previously suggested (Rosser 1997). Nevertheless guild regulations, even if not always completely successful, did regulate industries to a certain extent. One aspect that would have been taken more seriously was preventing individual men or trades from controlling production. Therefore, tanners and butchers were often specifically targeted because they supplied many other craftsmen with raw materials and were potentially in a powerful position to monopolise distribution (Kowaleski 1990). The organisation of urban work tended to divide up the production process preventing its control. Different craftsmen were given the right to inspect goods, thus helping to ensure that consumers were not being deceived by poor standard work.

The spatial expansion of London and the increase in its population from the 16th century have often been cited as crucial factors in the declining power of the guilds, necessitating a change in the organisation of work. Such changes are clearly evident in both the archaeological evidence and historical sources which reflect the relocation of industries from medieval cities to more suburban areas. In London, for instance, no more than 40 men of the leather-trades were to be found in the City in 1619 whilst 3000 were said to inhabit the suburbs (Unwin 1963). Suburban growth and the rise of outwork had the effect of reducing the independence of the individual craftsman who could not always rely on the power of a guild to ensure fair access to raw materials and equal opportunities in the sale of produce. An investigation into three types of industrial craftsmen, the tanners, the leatherdressers (who treated mainly sheep and goat hides with oil or alum to produce a lighter leather) and the horners, show how the organisation of work altered as supply of raw materials and control of production were effected by the move of the industries away from the City.

\section{The heavy (tanned) leather industry}

In the late medieval period a greater demand for leather was generated by the 
proliferation of craftsmen using it as a raw material. This diversification of the leather trades led to increased efforts to regulate and inspect the tanners' goods. In response to the increased tension between manufacturers and consumers, tanners moved away from areas controlled by the urban authorities. Complaints about the pollution of streams by tanners encouraged decisions that led to the relocation of the trade as it was being forced out of the City (Sabine 1933). At the same time the reduced export market for hides effectively lowered the status of tanners. Cheaper land in the suburbs was an added incentive. The growth of small towns also allowed tanners to operate away from the major urban centres which had, in the medieval period, provided the main source of hides and therefore determined the location of leather production (Kowaleski 1990).

The development of regional specialisation during the 16th and 17th centuries bolstered the success of some tanners. In several provincial towns the increased status of tanners is apparent with one such craftsman becoming mayor of St Albans in 1554 (Saunders 1977). In late 16th century Leicester a tanner was appointed mayor on three separate occasions (Kowaleski 1990). This indicates the prosperity and level of power that men in this craft could attain although such cases were probably men engaged in trade rather than manufacture.

In London the tanners benefited from laxer control over their industry. Curriers (who were responsible for treating tanned leather with oils) and cordwainers (shoemakers) continued to exercise limited searches over the quality of leather but often tanners, who organised their own supplies of hides from butchers, tended to be less constrained by the activities of the guilds. Technologically the manufacturing process remained unchanged. This prevented a few individuals from saturating the market entirely because large quantities of leather took too much time and space to produce.

\section{The light leather industry}

Turning to light leather production, from the late 15th century the majority of the leatherdressers had moved out of the City of London into the suburbs. The leatherdressers craft was not as pungent as that of the tanner but their presence in the City still gradually decreased. Since these general craftsmen were no longer shopkeepers, (Unwin 1963) their need to pay high rents in order to be close to customers became less crucial. Leatherdressers had long been affiliated with the Company of Leathersellers but gradually the traders lost touch with the craftsmen and the growing gulf between the two is evident in the leatherdressers repeated petitions for a charter to allow them greater trading rights. The technical differences between the light and heavy leather trades meant that the former could produce larger quantities of goods. However, their activities were limited by the leathersellers supplying hides and taking the sale of their produce out of their hands (Unwin 1963).

As with the heavy leather industry the manufacturing processes involved in light leather production did not evolve throughout the 16th or 17th century. At the end of the 18th century there is evidence for a dramatic increase in the number of leatherdressers in the leather-producing parishes of Southwark in south London (fig. 

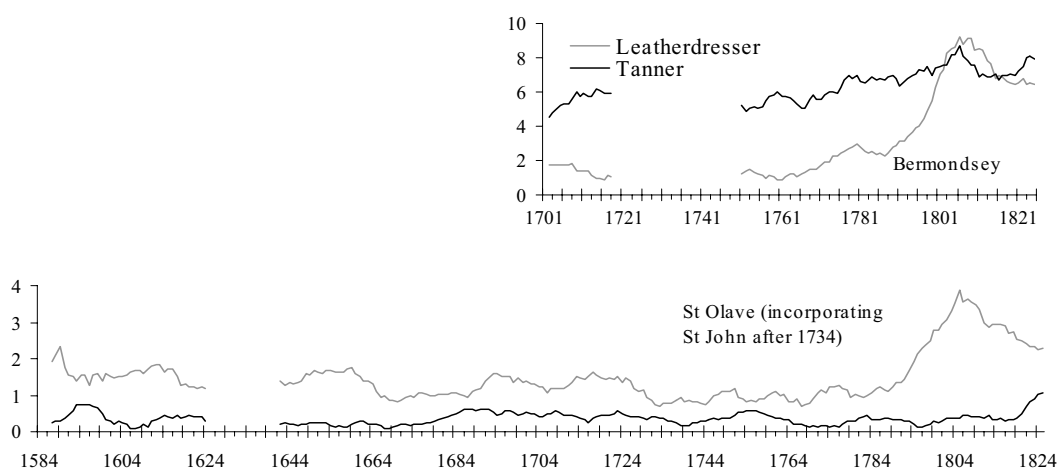

Fig. 8.1. Frequency of men (seven-year-moving average) working as leatherdressers and tanners in Bermondsey and St Olave (incorporating the parish of St John after 1734) based on the parish baptism registers.

8.1). This suggests that there was a significant development in the industry with the scale of production increasing. It may reflect a change in the organisation of the light leather industry as large operations of a factory type started to develop and the 'industrial revolution' took hold of the industry. A similar development did not occur in the tanning industry until the later part of the 19th century when the use of chromic acids drastically reduced the time needed to produce leather (Gomersall 2000). Comparison of faunal assemblages from earlier post-medieval leatherdressers' workshops across the country indicates a relatively standard way of processing skins. For example an assemblage dated 1450-1600 excavated in Leicester (Baxter 2004) was very similar to the bone from an early 18 th century deposit in York $\left(\mathrm{O}^{\prime} \mathrm{Connor} 1984\right)$ and remains at many of the London sites indicate similar methods for processing the hides. When the industry developed into a large-scale operation, as in London at the end of the 18th century and early 19th century, the changing level of production would probably affect the way that bone waste was dealt with. If the hides were still brought to the site with the bones attached then large quantities of bone waste would have to be cleared more systematically. Many of the 19th century timber-lined pits excavated in Southwark appear contain minimal quantities of animal bone although selective archaeological recovery from late post-medieval deposits may also be a factor.

\section{The horn-working industry}

The third industry utilizing parts of the animal carcass is hornworking. The London Horners Company had an extensive set of rules that were frequently modified and added to over the course of the 16th and 17th centuries (Compton 1879; Rosedale 1911, 1912; Fisher 1936). Many of these additions and amendments were aimed at ensuring the supply of raw material. These counteracted the many factors that meant that the industry was wide-open to competition. The horners' produce was a useful commodity 


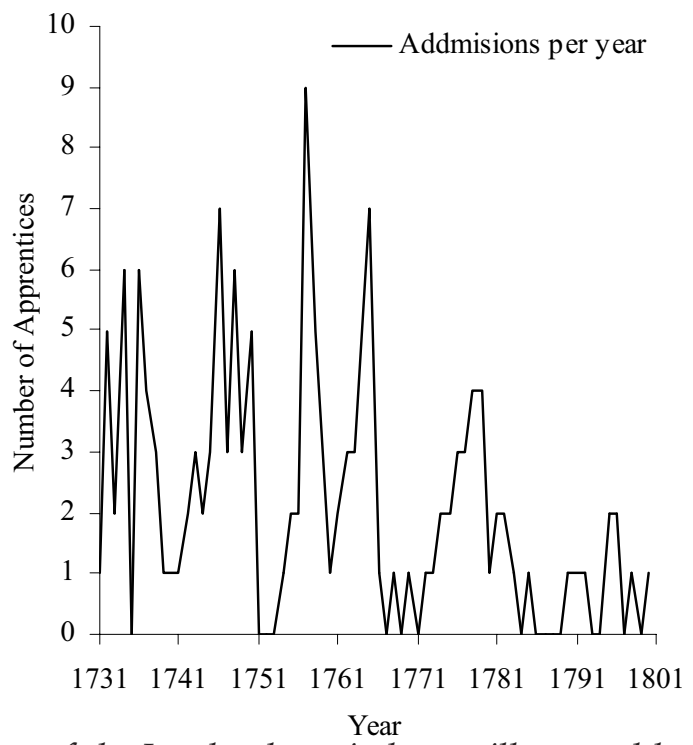

Fig 8.2. The decline of the London horn industry illustrated by falling apprenticeships.

although in London there would never have been any overwhelming demand that could not be met by the quantity of horn available from the carcasses of animals brought into the City to feed its population. These factors made it difficult for individual producers to control the industry. In effect the "simplicity of the tools, the cheapness of the raw materials, and the limited market for the finished product all made hornworking a trade peculiarly unfitted for the large capitalist" (Fisher 1936, 78). The Horners Company was prepared to undertake legal action against those who tried to undermine its control. An example of this occurred in 1689 when a combmaker was prosecuted for pressing horns (Compton 1879). Entry into the Company was strictly under apprenticeship allowing the Company to limit the number of horners in London in accordance with the level of demand. Additionally, master horners were allocated their share of a joint stock of horn according to their length of service, along with the greater allowance given to members who undertook duties to ensure the running of the guild. All these factors helped ensure that the Company members were able to earn a living. By the end of the 18th century the industry had gone into decline with cheaper glass production further reducing demand for the horners' produce. This is reflected in the number of apprentices starting their training (fig. 8.2) and, unlike the apprentice registers of some other companies (Walker 1986), the reduction in numbers in the later 18th century reflects the lowering demand for the horners' produce rather than the waning of guild control. Tracing the decline of the industry from zooarchaeological evidence is not as accurate because dating of the contexts where horners' waste have been found is not precise enough and the lack of deposits from specific dates may just reflect the extent of fieldwork rather than an actual change in the industries importance. 


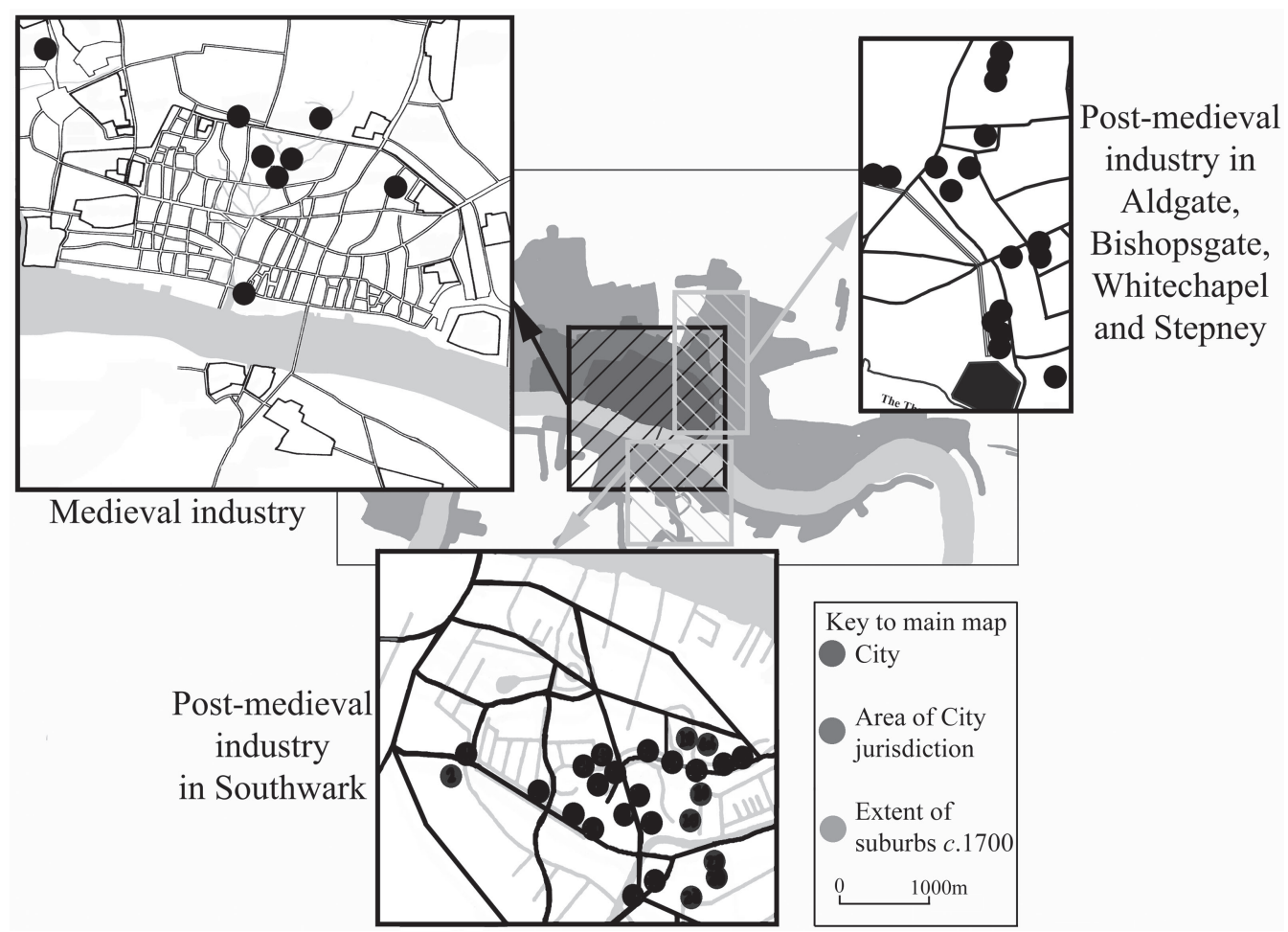

Fig 8.3. Zooarchaeological evidence for the location of industries processing animal carcasses in medieval and post-medieval London. In the eastern parishes the evidence is mainly from the horn-working industry and south of the river the evidence is largely remains of the leather industry.

\section{Changing organisation in carcass-processing industries}

These three cases show how the two types of leather producers and hornworkers were crafts whose organisation was altered in different ways by the frequently cited decline of the guilds and rise of capitalist production. Decisive factors seem to have been how effective individual craftsmen were at keeping control over raw material supplies and sale of produce. In the hornworking industry this was achieved because the profits never attracted capitalists and the guild remained in control. Prospects in the tanning industry were limited to certain extent by the production methods rather than market demand and this did not change until the 19th century. The craftsmen in light leather industry, however, did not retain as much control over their work. They suffered at the hands of the traders who began commanding the supply and sale of produce although their petitions against the leather-sellers controlling their industry may be somewhat exaggerated (Unwin 1963). The way that these industries dealt with economic change associated with the end of the medieval period aids our understanding of factors that were important to craftsmen in the medieval period and earlier. 
Fig 8.4. Occurrence of horners in the Lay Subsidy Rolls indicating the centres of hornworking in the medieval period (based on data in Curtis 1918 and Ekwall 1951).

\section{Archaeological evidence for industrial relocation}

Comparison of archaeological evidence from the Middle Ages through to the postmedieval period clearly shows the change in the geography of industries within London. The focus of leather production shifted towards the southern suburbs and, although significantly less so and not yet reflected by archaeological remains, into the eastern suburbs close to the river (fig. 8.3). The centre of hornworking, previously seen in the City or just outside the City wall, shifted into the eastern districts centred on Petticoat Lane with a smaller group continuing around the Fleet where archaeological evidence indicates a second concentration of the industry in the medieval period (fig. 8.4). Interestingly, only one horner has been identified in a study of the parish baptism registers of Bermondsey and St Olave in Southwark where raw materials would have been easily obtained from local tanning-yards. This provides further evidence that guild control over hornworking was still strong providing reason for members to congregate 


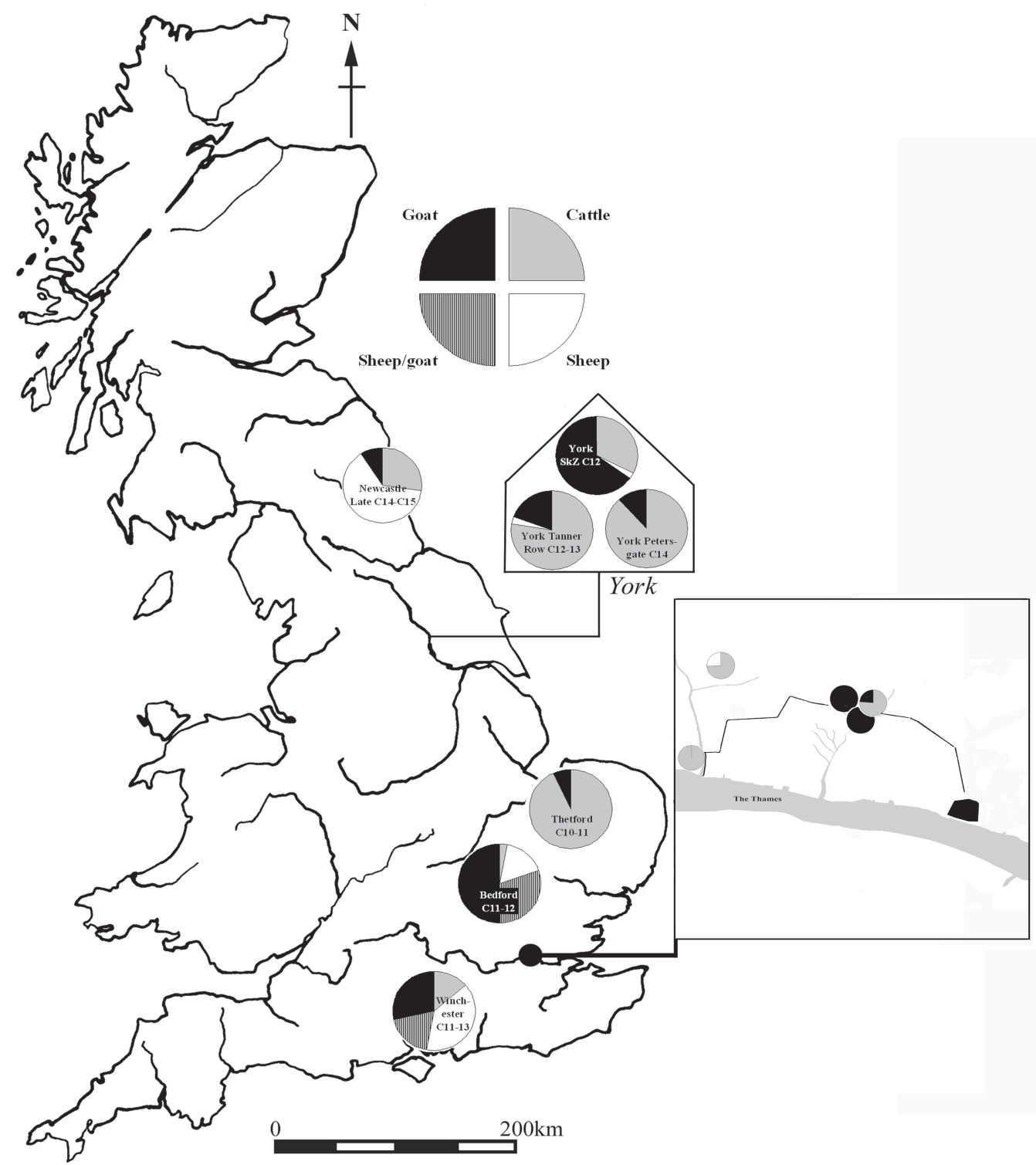

Fig 8.5. Selection of horn used by medieval horners.

spatially rather than follow the availability of raw materials. The frequent cattle horncore-lined pits found in Southwark therefore contained reused waste from tanneries rather than waste from hornworking, although the tanners often sold the horn-sheath on to horners. This also fits with a detailed examination of the horncores which, in Southwark, lack examples with sawn-off tips or sawn segments of horncore which are found in the horners' waste assemblages of East London. A manuscript from 1641 
listing members of the Horners Company and a study of occupations found in the East London parish registers, confirm the archaeological evidence for horners in East London.

\section{Supply networks and use}

Changes in the supply of animals coming into the City and used in the industries can also be identified in the archaeological record. Evidence for the hornworking industry has been found at a number of urban sites in England. The pie charts shown on Figure 8.5 illustrate the selection of raw materials by horners during the medieval period. The data is taken from faunal reports where hornworking was given as the most probable interpretation of horncore accumulations (Biddle 1990, Clutton-Brock and Armitage 1978, Drummond-Murray and Liddle 2003, Grant 1983, Jones 1984, O'Connor 1984, 1988, Rackham 1981, Ryder 1970). The hornworking craftsmen in urban centres evidently went to a great deal of effort to obtain goat horn since goats were a minority species even in rural areas (Grant 1988). This differs substantially to the evidence for the post-medieval centuries (fig. 8.6) when cattle and sheep were the main source of raw material for hornworking (Armitage 1978, Cram 1982, Hutchins and Steadman 1999, Noddle and Harcourt 1985, O'Connor 1991, Rackham 1981, Weinstock 2002). The graphs shown on this map (fig. 8.6) are based on evidence from sites dated to between the 16th and 18th centuries suggesting that horners in the post-medieval period were utilising horn supplied from different sources. The map only includes sites where horners' waste was given as the interpretation of the faunal assemblage and there is substantial evidence to suggest that sheep (but extremely rarely goat) horn was used by less specialised craftsmen. In London, historical evidence suggests that sites south of the river (see above) were not actually occupied by horners but that men in other trades such as the tanners, leatherdressers and butchers were removing horn for sale to the horners who occupied the area to the east of the City. Use of goat horn did not completely cease but there was a definite change. Some sixteenth century deposits in both Newcastle and London have produced evidence of goat horn working indicating the continued use of this animal for commercial production in towns.

\section{Factors affecting supply}

The effect of the traders' monopoly over animal products and distribution of raw materials to the manufacturers may be a possible explanation for the decreasing use of goat horn. In the early 17th century, for example, the leatherdressers had complained that for the past 20 years it had been practically impossible to find goat or kid leather unless they purchased it from one of three merchants of whom one was a freeman of the Leathersellers Company whilst the other two were not even leathersellers but members of the Haberdashers Company (Unwin 1963). This was, no doubt, an exaggeration on the part of the leatherdressers who were trying to make a point but it shows the effect that the control of trade could have on the supply of raw materials to manufacturers. Another factor may have been the process of enclosure. The 16th 


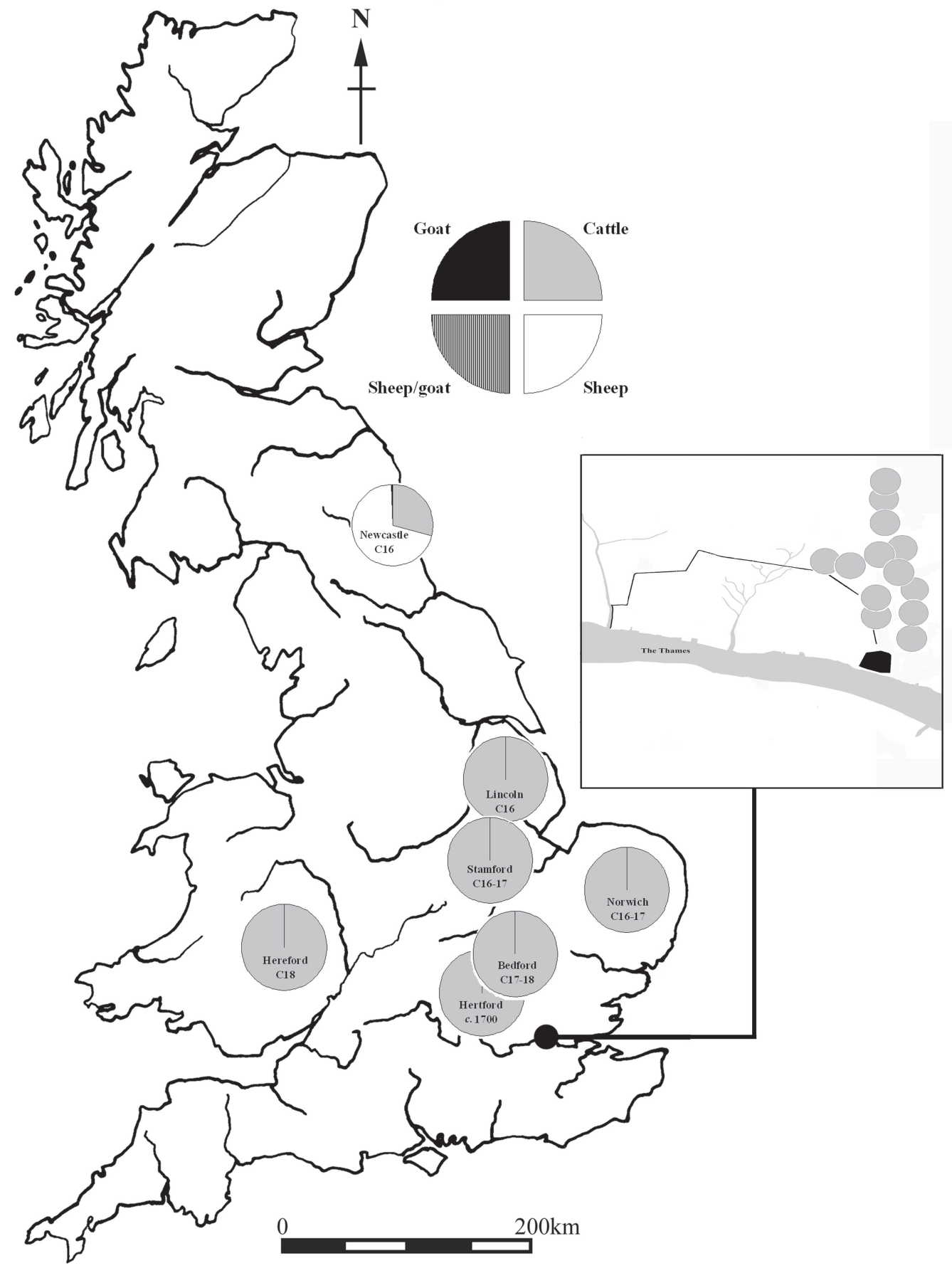

Fig 8.6. Selection of horn used by post-medieval horners. 

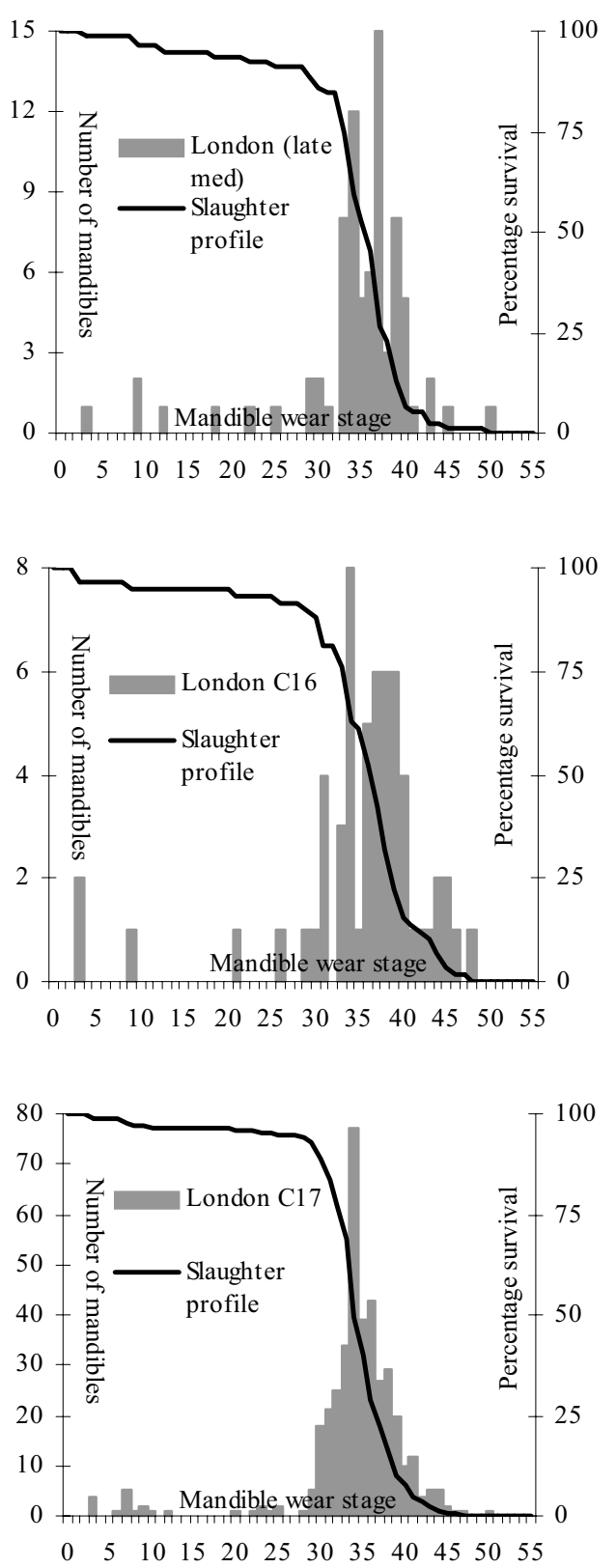

Fig 8.7. Mortality profiles of sheep slaughtered in London over the late medieval and earlier post-medieval periods. century witnessed the conversion of much common land into fields for sheep which offered greater profits from their wool yield and in turn their meat. The increase in sheep flocks and the reduction of common land for individuals to graze their own animals may have had an impact on the availability of products from other species.

The effect that changes in the countryside were having on the animal carcasses processed in towns is also notable in the ages of the animals driven into the City. The graphs shown in Figure 8.7 amalgamate evidence of mandible wear stages from late medieval, 16 th and 17th century sites within London and its suburbs that have been analysed during the course of the research to date. More work is needed to compare the profiles from different sites but at this stage the graphs crudely illustrate that sheep consumed in London were older animals. This reflects how the supply of animals into London and other urban centres (e.g. Oxford and Exeter (Wilson 1994, Maltby 1979) was influenced by the increase in the rural wool and cloth industries from the late medieval period. Once a sheep's fleece yield had started to decrease because of age, the animal would be driven to market and sold for meat. The results are similar to those obtained from the well-known wool producing area of Ypres (Ervynck 1998). There may have been a very slight increase in the proportion of older sheep killed in the London slaughterhouses in the early post-medieval period but it seems more likely that this just reflects sample size. Additional work is needed on faunal remains from the earlier medieval in London to indicate when there was a change in the age of sheep consumed inferring either a significant change in the rural use of sheep or the supply of meat animals to the City. 

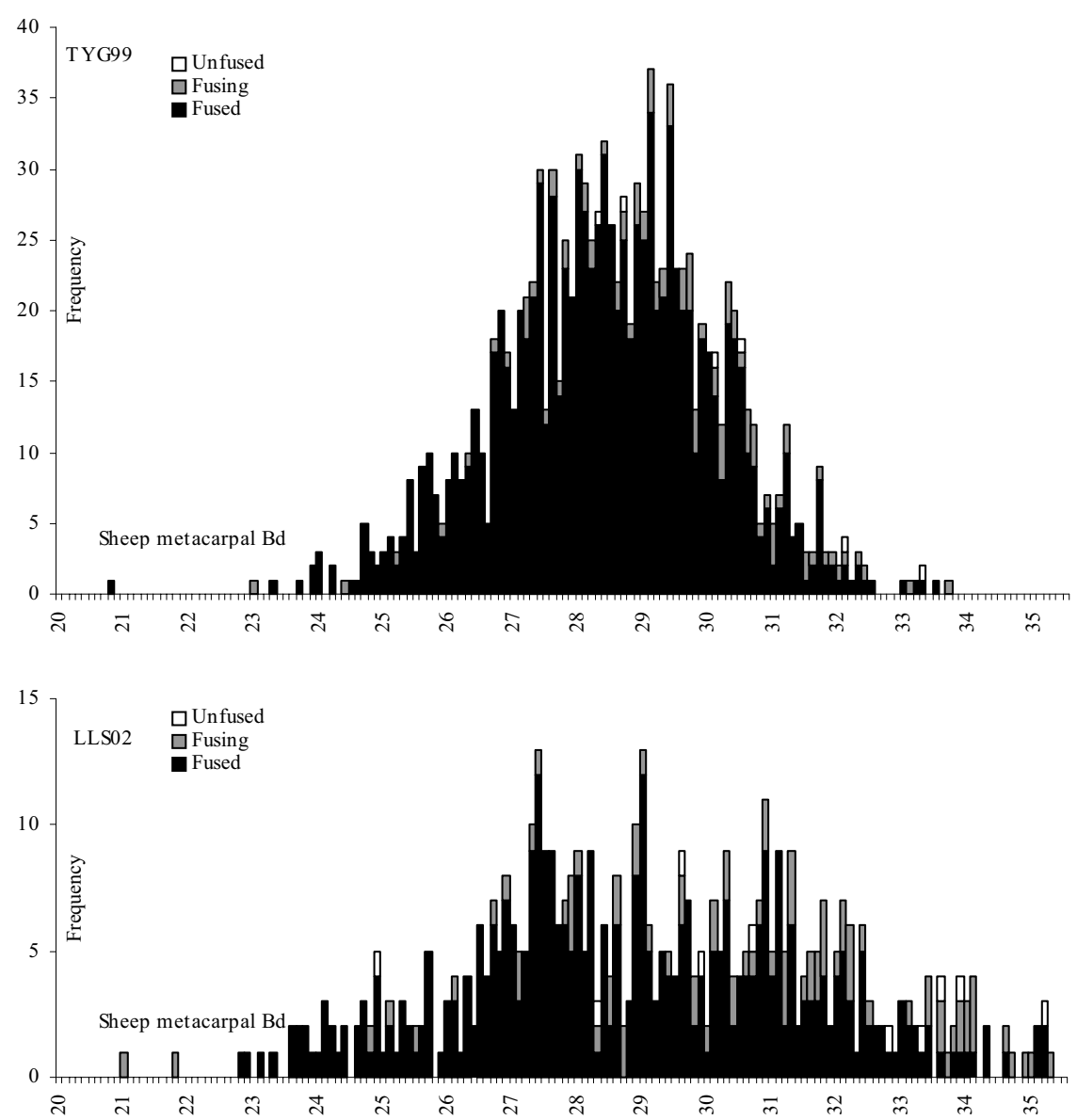

Fig 8.8. Sheep metacarpal measurements from two large assemblages of leatherdressers' waste reused to construct floor surfaces in Southwark.

A number of post-medieval deposits in London also suggest the presence of wethers again reflecting the importance of animals kept specifically for wool. This is best demonstrated by measurements taken on two large accumulations of leatherdressers' waste from Southwark that had been reused to construct floor surfaces (fig. 8.8). Both accumulations date to the 18th century and show that many of the largest bones (particularly at LLS02) were still fusing or even unfused (in the few cases where the epiphysis was recovered complete). These were probably bones from weathers whose bone fusion had been delayed by castration allowing them to continue growing. It is also interesting that the spread of measurements at the two sites is different. The higher variation in the LLS02 measurements suggests that some leatherdressers had access to a greater range of sheep probably from a variety of breed types. 


\section{Restrictions in use of local raw materials}

In the post-medieval period people started to import large quantities of raw materials from distant sources such as ivory and horn from Africa and India, yet the use of animals locally available became more restricted. The most notable aspect of this change is the almost nonexistent use of antler. This had been a widely used raw material particularly during the early medieval period but its importance gradually declined. By the post-medieval period, by-products from livestock supplied most of the animal materials used in towns. Animal products were also subjected to a widening range of production processes with craftsmen finding new ways of manipulating the carcasses of sheep and cattle to produce artefacts. One example is the changing typology in combs (as antler and bone forms were replaced by horn examples) which testifies to the changing use of animal carcasses (for example see Dunlevy 1972; Biddle 1990).

\section{Carcass utilisation in post-medieval London}

The evidence briefly described above as well as other zooarchaeological and historical data have been used in an attempt to model the variety of ways that animal carcasses were used in post-medieval London and the distribution of raw materials between craftsmen. The aim is compile further evidence from the medieval period in the future allowing comparison of the way in which animal carcasses were used. Changes in the way that animal carcasses were processed reflect socio-economic developments around the medieval/post-medieval transition since the governing regulations had to adapt to the changes in the organisation of work and production. The changing use of species is also a reflection of the agricultural developments at this time suggesting how the urban population focused on farmed animals with wild animals rarely used.

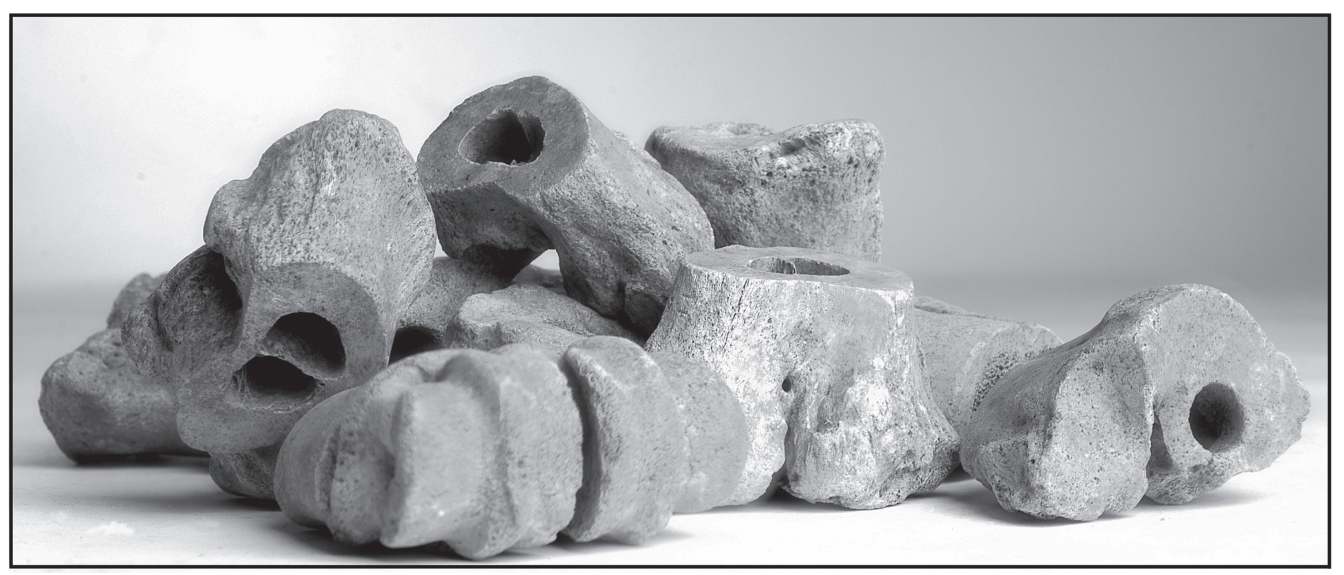

Fig 8.9. Cattle metacarpals that were off-cuts from bone working with holes drilled down through the medial side of the proximal articulation indicating they had passed through a tannery. 

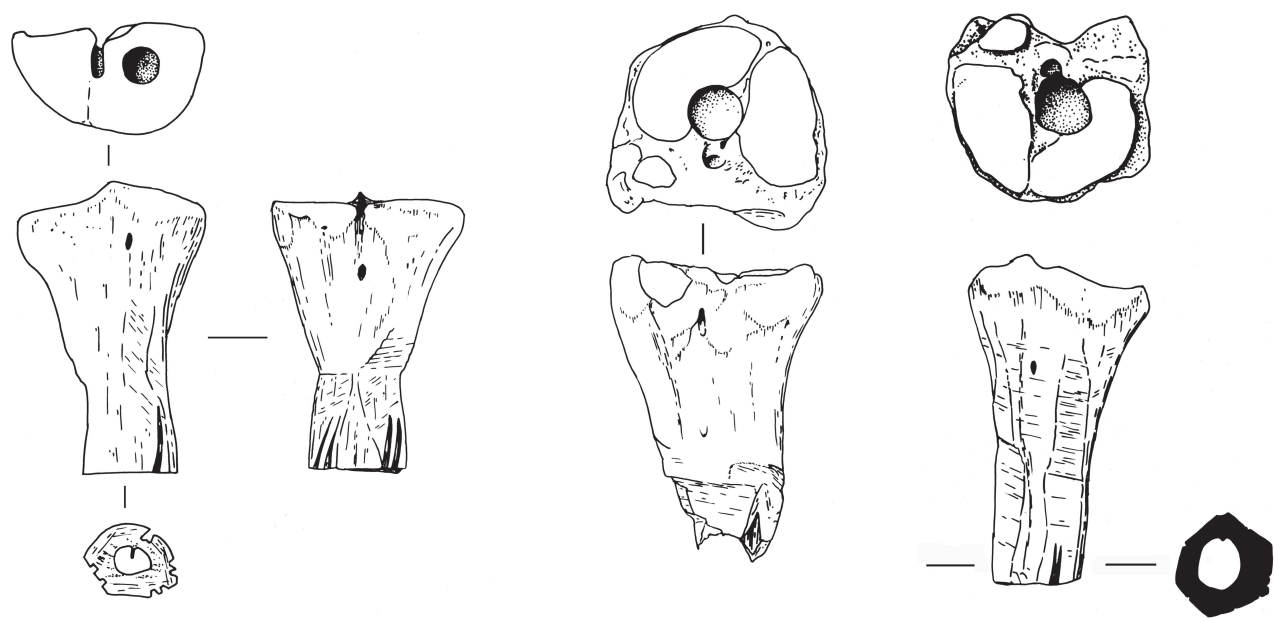

Fig 8.10. Pinners' bones manufactured from tannery waste (scale 1:4).

Industries processing animal carcasses were dependant upon one another for their raw materials. This is evident in the spatial location of butchers, tanners, leatherdressers and horners reconstructed through the parish registers and confirmed by modifications to bones. Using this data it is possible to suggest the networks that divided and used parts of the animal carcass. For instance, numerous sites have produced sheep skulls, frequently chopped down the line of the sagittal suture with the horncores chopped off by means of cleaver blows directed to their base. These occur in deposits where the faunal assemblage has been interpreted as both butchers and leatherdressers waste suggesting that the process was not confined to one tradesman. The trade in sheep horn was widespread and it seems that the opportunity to sell this part of the carcass on was rarely missed. Similarly, tanners sold cattle horn on to horners occasionally leaving evidence of horn removal but also historical references mention the profits that could be made from this activity (Burridge 1824, Hartridge 1955). Figure 8.9 shows a group of typical bone working waste with the proximal and distal ends of the metapodials sawn off and found together in one context. The hole drilled through the proximal articulation suggests that the bone-worker had been supplied from a tanner who probably drilled the hole to aid in the stretching of the hides. Such modifications have been identified at many tannery sites and in locations where there was no subsequent processing of the bone suggesting that some aspect of the tanning process must have been responsible. Similar modifications have been found on pinners' bones (fig. 8.10) indicating another way in which animal bones passed between craftsmen in different trades. Pinners were groups of craftsmen who made pins and would use grooves sawn into bones to hold pieces of wire as they sharpened them into pins.

A model of animal carcass use in the leather-producing suburbs in Southwark was generated on the basis of the types of evidence presented above. This is shown in Figure 8.11 illustrating the many uses that animal carcasses could be put to and the complicated distribution network allowing the different trades to obtain the parts of 


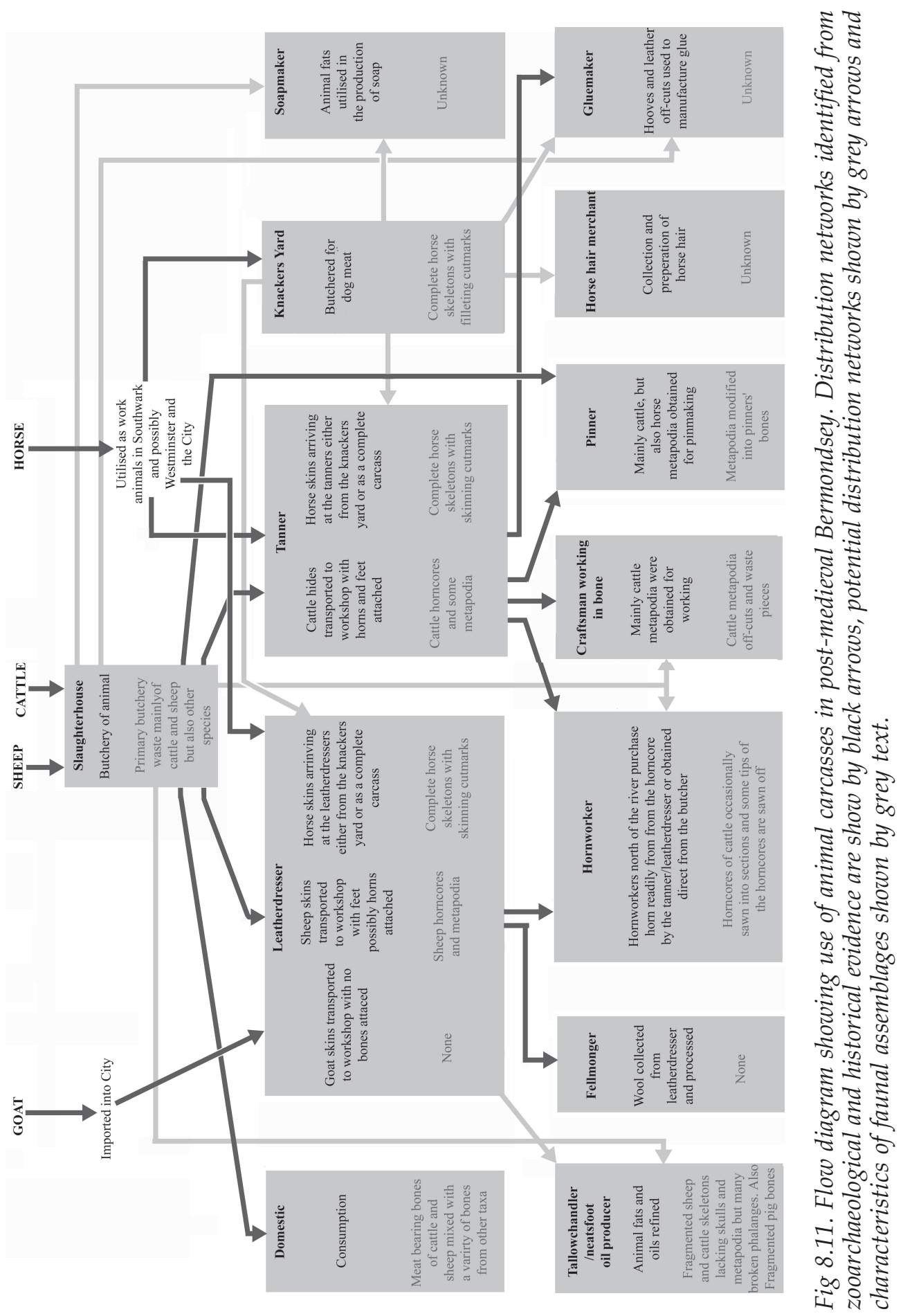


carcasses they needed or could use. The faunal assemblages that accumulated at different workshops are also shown based on the analyses from Southwark since they may prove useful to others working on industrial waste.

\section{Conclusions}

To conclude, the use of animal carcasses in medieval and post-medieval cities was affected by the organisation of work both in urban centres and in the countryside. It is just as important, therefore, to look at evidence for how production was controlled and the changes that occurred at the end of the medieval period to understand how carcasses were transformed into items of material culture during the medieval period. The supply of animal goods was partly affected by changes in the rural economy and, in the post-medieval period, by the desire for new and exotic materials. Post-medieval faunal evidence shows the complex distribution network needed to ensure that all the craftsmen gained access to raw materials. Similar supply systems must have operated in medieval London and it will be interesting to compare the two when more evidence is analysed.

\section{Acknowledgements}

The work presented in the paper is part of an ongoing student research project supported by the AHRC and supervised by Drs. Jane Sidell and Louise Martin. The London Archaeological Archive and Research Centre, Kevin Rielly and Pre-Construct Archaeology provided access to assemblages and grey literature. The London Metropolitan Archive and the Guildhall Library provided additional help. Thanks also to the reviewer for commenting on the paper.

\section{Bibliography}

Armitage, P. L. (1978) Hertfordshire cattle and London meat markets in the 17th and 18th centuries. London Archaeologist 3, 217-223.

Baxter, I. L. (2004) Animal, bird, reptile and amphibian bones. In N. Finn The Origins of a Leicester Suburb: Roman, Anglo-Saxon, Medieval and Post-medieval Occupation on Bonners Lane, 132-148. Oxford, British Archaeological Reports, British Series.

Biddle, M. (1990) The nature and chronology of bone, antler and horn working in Winchester. In M. Biddle (ed.) Object and Economy in Medieval Winchester, Volume II, 252 264. Oxford, Claredon Press.

Burridge, J. (1824) The Tanner's Key. London.

Clutton-Brock, J. and Armitage, P. L. (1977) Mammal remains from trench A. In (T. R. Blurton), Excavations at Angle Court, Walbrook, 1974. Transactions of the London and Middlesex Archaeological Society 28, 88-97.

Compton, C. H. (1879) The horners of the City of London. British Archaeological Journal 35, 372379. 
Cram, L. (1982) The pits and horn cores. In C. Mahany, A. Buchard and G. Simpson (eds.) Excavations in Stamford, Lincolnshire, 1968-1969, 48-51. The Society for Medieval Archaeology Monograph Series No. 9.

Curtis, M. (1918) The London Lay Subsidy of 1332. In G. Unwin, (ed.) Finance and Trade Under Edward III, 35-60. Manchester, The University Press.

Drummond-Murry, J. and Liddle, J. (2003) Medieval industry in the Walbrook valley. London Archaeologist 10, 87-94.

Dunlevy, M. (1972) Some comb forms of the fifteenth to eighteenth centuries. North Munster Antiquarian Journal 15, 22-27.

Ekwall, E. (1951) Two Early London Subsidy Rolls. Lund, C.W.K. Gleerup.

Ervynck, A. (1998) Wool or mutton? An archaeological investigation of sheep husbandry around late medieval Ypres. In M. Dewilde, A. Ervynck and A. Wielemans, A. (eds.) Ypres and the Medieval Cloth Industry in Flanders: Archaeological and Historical Contributions, 77-88. Flanders, Institute for Archaeological Heritage.

Fisher, M. A. (1936) A Short history of the Worshipful Company of Horners. London.

Gomersall, M. (2000) Departed glory: the archaeology of the Leeds tanning industry 17801914. Industrial Archaeology Review 22, 133-144.

Grant, A. (1983) The animal bones. In (J. Hassall) Excavations in Bedford 1977 and 1978. Bedfordshire Archaeological Journal 13, 70-72.

Grant, A. (1988) Animal resources. In G. Astill and A. Grant (eds.) The countryside of medieval England, 149-187. Oxford, Blackwell.

Hartridge, R. J. (1955) The Development of Industries in London South of the Thames 1750 to 1850. Unpublished MSc Thesis, University of London.

Hutchins, E. and Steadman, S. (1999) Evidence for 17th and 18th century cattle improvements. Environmental Archaeology 4, 87-92.

Jones, G. (1984) Animal bones. In A. Rogerson and C. Dallas (eds.) Excavations in Thetford 194859 and 1973-80, 187-192. Dereham, East Anglian Archaeology Report No. 22.

Kowaleski, M. (1990) Town and country in late medieval England: The hide and leather industry. In P. J. Corfield and D. Keene (eds.) Work in Towns: 850-1850, 57-73. Leicester, Leicester University Press.

Maltby, M. (1979) Faunal Studies on Urban sites: the Animal Bones from Exeter 1971-1975. Sheffield, University of Sheffield, Department of Prehistory and Archaeology.

Marsall ,T. H. (1929) Capitalism and the decline of the English guilds. Cambridge Historical Journal 3(1), 23-33.

Noddle, B. A. and Harcourt, R. (1985) The animal bones. In R. Shoesmith (ed.) Hereford City Excavations 3, 84-94. London, Council for British Archaeology Research Report 56.

O'Connor, T. P. (1984) Selected groups of Bones from Skeldergate and Walmgate. York: York Archaeology Trust.

O'Connor, T. P. (1988) Bones from the General Accident Site, Tanner Row. York, York Archaeology Trust.

O'Connor, T. P. (1991) The animal bone. In D. Stocker (ed.) St. Mary's Guildhall, Lincoln: the Survey and Excavation of a Medieval Building Complex, 88-91. Lincoln, City of Lincoln Archaeology Unit, The Archaeology of Lincoln Vol. XII-1.

Rackham, J. (1981) The animal remains. In (B. Harbottle and M. Ellison) An excavation in the castle ditch, Newcastle upon Tyne, 1974-6. Archaeologia Aeliana 21, 229-243.

Rosedale, H. C. (1911) Some Notes on 'The Old Book' of the Worshipful Company of Horners. London, The Worshipful Company of Horners.

Rosedale, H. G. (1912) A Short History of the Worshipful Company of Horners. London, Blades, East and Blades. 
Rosser, G. (1997) Crafts, guilds and the negotiation of work in the medieval town. Past and Present 154, 3-31.

Ryder, M. L. (1970) The animal remains from Petergate, York, 1957-58. Yorkshire Archaeological Review Journal 42, 418-428.

Sabine, E. L. (1933) Butchering in medieval London. Speculum 8, 335-353.

Saunders, C. (1977) A sixteenth century tannery in St Albans. Herefordshire Past 3, 9-12.

Unwin, G. (1963) Industrial Occupations in the Sixteenth and Seventeenth Centuries. London, Frank Cass and Co, Ltd.

Walker, M. (1986) The Extent of Guild Control in England c.1660-1820. Unpublished PhD Thesis, University of Cambridge.

Weinstock, J. (2002) The medieval and post-medieval bone remains. In M. Atkin, and D. H. Evans. (eds.) Excavations in Norwich 1971-1978 Part III, 220-230. East Anglian Archaeology Reports No. 100.

Wilson, B. (1994) Mortality patterns, animal husbandry and marketing in and around medieval and post-medieval Oxford. In A. R. Hall and H. K. Kenward (eds.) Urban-Rural Connections: Perspectives from Environmental Archaeology, 103-115. Oxford, Oxbow. 